\title{
Altered 5-HT-Induced Calcium Response in the Presence of Staurosporine in Blood Platelets from Bipolar Disorder Patients
}

\author{
Katsuji Suzuki*,', Ichiro Kusumi', Tatsuyuki Akimoto', Yuki Sasaki' and Tsukasa Koyama' \\ 'Department of Psychiatry, Hokkaido University Graduate School of Medicine, Japan
}

\begin{abstract}
We have reported that the platelet intracellular calcium (Ca) mobilization after stimulation by serotonin (5-HT) is specifically enhanced in bipolar disorder among various psychiatric disorders, compared with that in normal control. To explore the mechanisms of enhanced $\mathrm{Ca}$ response to $5-\mathrm{HT}$ in the platelets, we first examined the relation between the $5 \mathrm{HT}$-elicited Ca mobilization and 5- $\mathrm{HT}_{2 \mathrm{~A}}$ receptor density using the platelets from 13 normal subjects. From this study, we found no significant correlation between two measures. Then, we investigated the effects of staurosporine, a protein kinase C (PKC) inhibitor, on Ca response to 5-HT in platelets from patients with major depressive disorder (unipolar), bipolar disorder, and normal controls. While 5-HT-induced Ca mobilization, in the presence of I $00 \mathrm{nM}$ staurosporine, was significantly attenuated in normal controls and patients with major depressive disorder, the inhibitory effect of staurosporine was not observed in bipolar disorder. These results suggest that the failure in inhibiting the platelet intracellular Ca response to 5-HT in bipolar disorder may be related to increased activity of PKC rather than increased $5-\mathrm{HT}_{2 \mathrm{~A}}$ receptor number. Moreover, the trend of the Ca response towards staurosporine may become a specific biological marker for unipolar-bipolar dichotomy. Neuropsychopharmacology (2003) 28, 1210 - 1214, advance online publication, 2 April 2003; doi: I 0.1038/sj.npp. 1300159
\end{abstract}

Keywords: bipolar disorder; unipolar depression; protein kinase C; serotonin receptor; platelet; calcium

\section{INTRODUCTION}

We have reported that serotonin (5-HT)-induced intracellular calcium (Ca) mobilization in platelet is enhanced in drug-naive patients with some types of affective disorders (Kusumi et al, 1991b, 1994; Suzuki et al, 2001). Other researchers (Mikuni et al, 1992; Eckert et al, 1993; Okamoto et al, 1994; Tomiyoshi et al, 1999) have obtained similar findings. The enhancement in $\mathrm{Ca}$ response to 5-HT continues after remission, which indicates that this response may be a trait-dependent rather than a statedependent marker (Kusumi et al, 1994; Tomiyoshi et al, 1999). Furthermore, we reported in a naturalistic follow-up study that patients with enhanced Ca mobilization exhibited good response to mood stabilizers such as lithium or valproate (Kusumi et al, 2000). Thus, exploring the mechanism of this enhancement might contribute to our understanding of the underlying pathophysiology of affective disorders.

*Correspondence: Dr K Suzuki, Department of Psychiatry, Hokkaido University Graduate School of Medicine, North 15, West 7, Sapporo 060-8638, Japan, Tel: +8I I| 716 | |6lext. 5973, Fax: +8I || 706 508।, E-mail: kasuzuki@med.hokudai.ac.jp

Received 29 July 2002; revised 17 December 2002; accepted 03 January 2003

Online publication: 10 January 2003 at http://www.acnp.org/citations/ Npp0। 1003455
The 5-HT-induced intracellular Ca mobilization in human platelets was mediated by $5-\mathrm{HT}_{2 \mathrm{~A}}$ receptors (Kagaya et al, 1990; Kusumi et al, 1991a). Stimulation of $5-\mathrm{HT}_{2 \mathrm{~A}}$ receptors in human platelets increases phosphoinositide hydrolysis through Gq type $\mathrm{G}$ protein, producing inositol triphosphate, which mobilizes intracellular Ca from internal storage sites (Rittenhouse-Simmons, 1979; Affolter et al, 1984; de Chaffoy de Courcelles et al, 1985). As previously suggested in depressed patients in several studies (Arora and Meltzer, 1989; Pandey et al, 1990; Hrdina et al, 1995; Sheline et al, 1995), one possible explanation for enhanced $\mathrm{Ca}$ mobilization stimulated by 5 - $\mathrm{HT}$ is that increased density of $5-\mathrm{HT}_{2 \mathrm{~A}}$ receptor binding sites in platelets causes larger $\mathrm{Ca}$ response to 5-HT. Enhanced Ca mobilization can be also explained by the altered $5-\mathrm{HT}_{2 \mathrm{~A}}$-receptor function caused by enhanced transduction of stimuli through a postreceptor mechanism, that is, coupling between the receptor and G protein, or regulation of a second- or thirdmessenger pathway involving protein kinase. Recently, enhanced protein kinase C (PKC) activities in platelet or brain in affective disorders has been observed by some investigators (Friedman et al, 1993; Wang and Friedman, 1996; Pandey et al, 1998; Wang et al, 1999).

In this pilot study, for the purpose of elucidating a relation between the density of $5-\mathrm{HT}_{2 \mathrm{~A}}$ receptors and the degree of intracellular $\mathrm{Ca}$ response after 5HT stimulation, we measured these two markers simultaneously in the same blood sample from normal subjects. Furthermore, we 
examined the effects of staurosporine, a PKC inhibitor, on 5-HT-induced $\mathrm{Ca}$ increase in the platelets from not only healthy subjects but also patients with major depressive disorder and bipolar disorder, in order to confirm the involvement of PKC in the enhanced Ca response to 5-HT.

\section{MATERIALS AND METHODS}

\section{Materials}

Serotonin (5-hydroxytryptamine) creatinine sulfate was purchased from Sigma Chemical Co. (St Louis, MO). $\left[{ }^{3} \mathrm{H}\right]$ ketanserin $(66.4 \mathrm{Ci} / \mathrm{mmol})$ from Dupont New England Nuclear (Boston, MA). Fura-2/acetoxymethyl ester (fura-2/ AM) from Dojindo Lab. (Kumamoto, Japan). Staurosporine was kindly donated by Asahi-kasei Co. (Shizuoka, Japan).

\section{Subjects}

For the simultaneous measurement of $5-\mathrm{HT}_{2 \mathrm{~A}}$ receptor binding and 5-HT-induced $\mathrm{Ca}$ mobilization, subjects were 13 healthy male volunteers, whose mean age $( \pm$ SEM) was $35.5 \pm 7.2$ years. For the effects of several doses of staurosporine on $\mathrm{Ca}$ response to 5-HT, eight healthy subjects (four men, four women, $30.0 \pm 1.8$ years) participated in the study. In all, 11 patients with major depressive disorder (six men, five women, $37.4 \pm 4.4$ years), 10 patients with bipolar disorder (five men, five women, $37.3 \pm 3.8$ years), and 11 sex- and age-matched normal controls (six men, five women, $38.0 \pm 2.5$ years) participated in the comparison study. Written informed consent was obtained from all participants prior to blood sampling, which was approved by the Institutional Review Board in Hokkaido University School of Medicine. Patients were all drug-naive outpatients. A total of 10 subjects including two patients in manic episode and eight patients in depressive episode at the time of sampling were diagnosed using DSMIV criteria as bipolar disorders. Patients who met the DSMIV criteria for major depressive episode but had never experienced manic or hypomanic episodes were diagnosed as having unipolar major depressive disorder. All normal volunteers did not have any histories of psychiatric illness, family histories, and subsyndromal symptoms at the time of sampling. For at least 4 weeks before blood sampling all subjects had not received drugs such as aspirin that might interfere with platelet aggregation. They were free of physical illness including hypertension at the time of sampling.

\section{Blood Sampling}

Blood samples were taken from the antecubital vein and were anticoagulated by the addition of acid citrate dextrose ( $93 \mathrm{mM}$ sodium citrate, $213 \mathrm{mM}$ citric acid, $111 \mathrm{mM}$ glucose; $1 \mathrm{vol} / 9 \mathrm{vol}$ of blood).

\section{5- $\mathrm{HT}_{2 \mathrm{~A}}$ Receptor Binding Assay}

A volume of $63 \mathrm{ml}$ of venous blood taken from a subject was divided into $9 \mathrm{ml}$ for the measurement of intracellular $\mathrm{Ca}$ concentration and $54 \mathrm{ml}$ for receptor binding assay. Both experiments were performed simultaneously and started immediately after blood sampling. Isolated platelets were homogenized with a Polytron (setting 6.0) in hypotonic buffer (Tris- $\mathrm{Na}_{2}$ EDTA $5 \mathrm{mM}$, pH 7.5). Platelet membranes were collected and centrifuged for $20 \mathrm{~min}$ at $30000 \mathrm{~g}$ at $4^{\circ} \mathrm{C}$. The pellets were washed twice in $50 \mathrm{mM}(\mathrm{pH}$ 7.7) Tris- $\mathrm{HCl}$ buffer by successive centrifugations for $10 \mathrm{~min}$ at $30000 \mathrm{~g}$ at $4{ }^{\circ} \mathrm{C}$. The final washed platelet membranes were suspended in the same buffer in a concentration corresponding to $1 \times 10^{9}$ original platelets $/ \mathrm{ml}$.

Incubation mixtures were composed of $0.3 \mathrm{ml}$ platelet membrane preparation, $0.05 \mathrm{ml}$ of incubation buffer $(50 \mathrm{mM}$ Tris- $\mathrm{HCl}, \mathrm{pH} 7.7$ for total binding), or cold-displacing drug $(10 \mu \mathrm{M}$ methysergide, to define nonspecific binding), $0.05 \mathrm{ml}\left[{ }^{3} \mathrm{H}\right]$ ketanserin. The incubation was run for $15 \mathrm{~min}$ at $37^{\circ} \mathrm{C}$. The reaction was terminated by rapid filtration over Whatman GF/B filters presoaked by $0.1 \%$ polyethylenimine, which were rinsed twice with ice-cold $50 \mathrm{mM}$ Tris- $\mathrm{HCl}$ buffer ( $\mathrm{pH} 7.7$ at $25^{\circ} \mathrm{C}$ ) using a 24-well cell harvester (Brandel, USA).

For saturation experiments, six concentrations of $\left[{ }^{3} \mathrm{H}\right] \mathrm{ke}-$ tanserin (0.1-3.2 nM) were used. The dissociation constant $\left(K_{\mathrm{D}}\right)$ and density $\left(B_{\max }\right)$ of $5-\mathrm{HT}_{2 \mathrm{~A}}$ receptors were estimated using the nonlinear regression program EBDA/LIGAND.

\section{Measurement of 5-HT-Induced Intracellular Ca Mobilization}

The isolation of platelets and the measurement of intracellular $\mathrm{Ca}$ concentration were performed as described previously (Kusumi et al, 1991a, b, 1994). Briefly, plateletrich plasma (PRP) was prepared by centrifugation at $200 \mathrm{~g}$ for $10 \mathrm{~min}$ at room temperature. After $15 \mathrm{~min}$ incubation with $4 \mu \mathrm{M}$ fura-2/AM, platelets were isolated from the PRP by further centrifugation at $650 \mathrm{~g}$ for $15 \mathrm{~min}$. The resulting platelet pellet was suspended at $1 \times 10^{8}$ cells $/ \mathrm{ml}$ in KrebsRinger HEPES buffer $(145 \mathrm{mM} \mathrm{NaCl}, 5 \mathrm{mM} \mathrm{KCl}, 1 \mathrm{mM}$ $\mathrm{MgSO}_{4}, 0.5 \mathrm{mM} \mathrm{Na}_{2} \mathrm{HPO}_{4}, 6 \mathrm{mM}$ glucose, $10 \mathrm{mM}$ HEPES, $1 \mathrm{mM} \mathrm{CaCl}_{2}, \mathrm{pH}$ 7.4). The samples were prewarmed in a cuvette at $37^{\circ} \mathrm{C}$ for $4 \mathrm{~min}$ with staurosporine that was dissolved in Krebs-Ringer HEPES buffer or an equivalent volume of Krebs-Ringer HEPES buffer as control, and then $10 \mu \mathrm{M} 5$-HT was added to the incubation medium. Fluorescence was measured on a Hitachi F-2000 fluorometer with excitation at 340 and $380 \mathrm{~nm}$, and with emission at $510 \mathrm{~nm}$. Intracellular $\mathrm{Ca}$ concentrations were calculated from the ratio of fluorescence intensities at two excitation wavelengths in the platelet samples according to the method of Grynkiewicz et al (1985). We examined the maximum Ca response $(\mathrm{Ca}$ increase $=$ initial peak $(\mathrm{nM})-$ resting level $(\mathrm{nM})$ ) after stimulation by 5 -HT. The intraassay coefficient of variation (CV) was $4.7 \%$ and the interassay CV $11.2 \%$ as described in the previous report (Kusumi et al, 1991a).

\section{Statistical Analysis}

Values are expressed as means \pm SEM. Pearson's correlations were used to assess the inter-relations between intraplatelet $\mathrm{Ca}$ response and the $B_{\max }$ or $K_{\mathrm{D}}$ of $5-\mathrm{HT}_{2 \mathrm{~A}}$ receptors. The effect of several doses of staurosporine on $\mathrm{Ca}$ increase was examined using a one-factor repeated measures of ANOVA followed by Dunnet's test. The effect of $100 \mathrm{nM}$ staurosporine on $\mathrm{Ca}$ increase for each group was 
determined with paired $t$-test. Comparing intracellular $\mathrm{Ca}$ response among the three groups, data were analyzed for statistical significance by one-way ANOVA for multiple comparisons followed by Scheffe's test.

\section{RESULTS}

In the study investigating the relation between $\mathrm{Ca}$ increase and $5-\mathrm{HT}_{2 \mathrm{~A}}$ receptor number, the maximal increase of intracellular Ca concentration after $10 \mu \mathrm{M}$ 5-HT stimulation ranged from 36.8 to $128 \mathrm{nM}$ with a standard deviation of $31.3 \mathrm{nM}$. The $B_{\max }$ of $5-\mathrm{HT}_{2 \mathrm{~A}}$ receptors were from 7.6 to $13.5 \mathrm{fmol} / \mathrm{mg}$ protein with a standard deviation of $1.8 \mathrm{fmol} /$ $\mathrm{mg}$ protein. The $K_{\mathrm{D}}$ of $5-\mathrm{HT}_{2 \mathrm{~A}}$ receptors ranged from 0.24 to $0.84 \mathrm{nM}$ with a standard deviation of $0.16 \mathrm{nM}$. There were no significant correlations between the magnitude of 5-HTinduced $\mathrm{Ca}$ response and the $B_{\max }(r=0.109, p=0.730)$ (Figure 1) or $K_{\mathrm{D}}(r=0.386, p=0.198)$ of $5-\mathrm{HT}_{2 \mathrm{~A}}$ receptors.

As shown in Figure 2, there is no remarkable change in 5HT-induced Ca increase when preincubated with staurosporine at lower concentrations than $10 \mathrm{nM}$, while $\mathrm{Ca}$

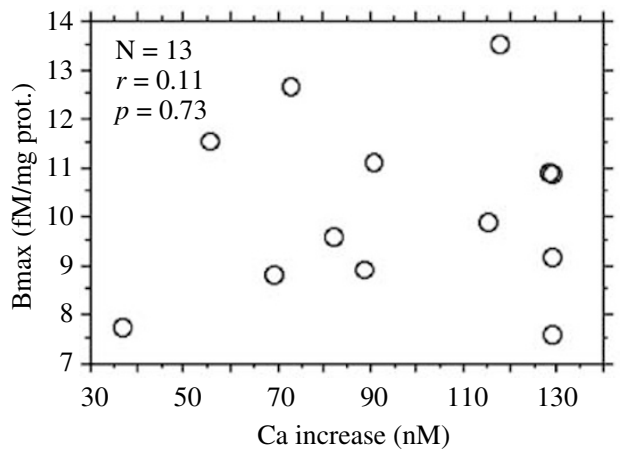

Figure I Correlation between 5-HT-induced $\mathrm{Ca}$ increase and $B_{\max }$ of $5-\mathrm{HT}_{2 \mathrm{~A}}$ receptors in the platelets of healthy controls. Pearson's correlations were used to assess inter-relations. Statistical significance was assigned at a level of $p<0.05$

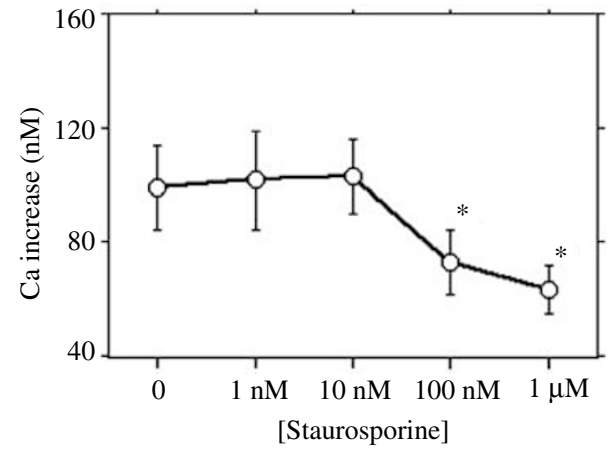

Figure 2 Effect of preincubation with staurosporine on $10 \mu \mathrm{M} 5-\mathrm{HT}$ induced platelet intracellular $\mathrm{Ca}$ mobilization. Platelet suspension was prewarmed for $4 \mathrm{~min}$ in the presence of various concentrations of staurosporine. One-factor repeated measures of ANOVA was performed to analyze an effect of staurosporine. Significant modulating action of staurosporine was observed on $5-\mathrm{HT}$-induced $\mathrm{Ca}$ response $(\mathrm{df}=4$, $F=|I .6, N=8, p<0.000|$ ). ${ }^{*} p<0.0 \mid$ compared with the data in the absence of staurosporine; calculated by Dunnett's test.

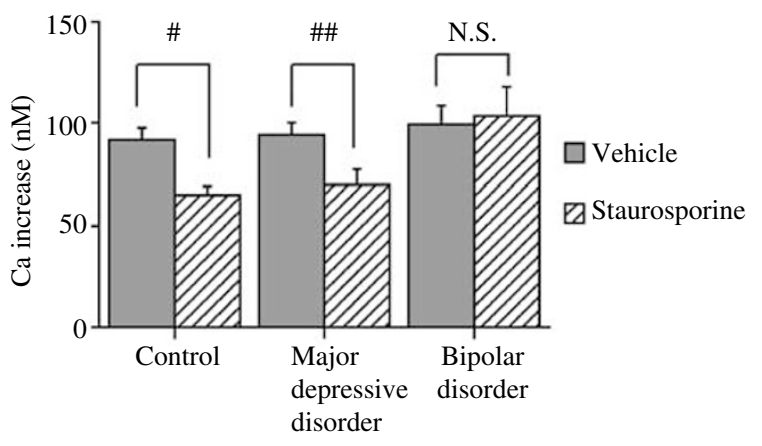

Figure 3 Effect of $100 \mathrm{nM}$ staurosporine on 5-HT-induced Ca increase in the platelets with normal controls and unmedicated patients with affective disorders. Platelet suspensions from the same individual were prewarmed for $4 \mathrm{~min}$ in the presence or absence (which is mentioned as vehicle) of $100 \mathrm{nM}$ staurosporine. Paired $t$-test was performed to determine the effect of $100 \mathrm{nM}$ staurosporine. $\# p=0.000$ I for normal control $(N=\mathrm{II})$; $\# \# p=0.0017$ for major depressive disorder $(N=\mathrm{II})$; nonsignificant (NS) effect observed in bipolar disorder $(N=10)$.

increases induced by 5-HT were significantly reduced when platelets were incubated in the presence of $100 \mathrm{nM}$ or $1 \mu \mathrm{M}$ staurosporine compared with those in the absence of staurosporine (control) $(72.3 \%$ of control for $100 \mathrm{nM}$, $64.9 \%$ of control for $1 \mu \mathrm{M}$ staurosporine, $p<0.01$ for each dose).

There was no significant difference in 5-HT-induced Ca increase between the three groups $(\mathrm{df}=2, \mathrm{~F}=0.275$, $p=0.761: 91.7 \pm 6.4 \mathrm{nM}$ for normal controls; $94.7 \pm 5.9 \mathrm{nM}$ for patients with major depressive disorder; $99.3 \pm 9.2 \mathrm{nM}$ for patients with bipolar disorder). In the presence of $100 \mathrm{nM}$ staurosporine, Ca increases elicited by 5 - $\mathrm{HT}$ in not only normal control but also major depressive disorder were markedly lower than that in the absence of staurosporine (vehicle) $(71.2 \pm 3.8 \%$ of vehicle, $p<0.0001$ for normal control; $74.0 \pm 5.7 \%$ of vehicle, $p=0.0017$ for major depressive disorder) (Figure 3). However, 5-HT-induced Ca mobilization in bipolar disorder was not changed when preincubated with $100 \mathrm{nM}$ staurosporine $(102.0 \pm 8.1 \%$ of vehicle, $p=0.5888$ ) (Figure 3 ).

\section{DISCUSSION}

Several investigators have indicated increased $5-\mathrm{HT}_{2 \mathrm{~A}}$ receptor density in the frontal cortex (McKeith et al, 1987; Yates et al, 1990) or in the platelets (McBride RA et al, 1983; Biegon et al, 1987; Arora and Meltzer, 1989; Pandy et al, 1990; Hrdina et al, 1995; Sheline et al, 1995) of depressed patients. However, these findings have not always been confirmed (Cowen et al, 1987; Cheetham et al, 1988; McBride et al, 1994; Neuger et al, 1999). The number of platelet $5-\mathrm{HT}_{2 \mathrm{~A}}$ binding sites in manic subjects has also been reported to be the same as in controls (Velayudhan et $a l$, 1999). Furthermore, decreased $5-\mathrm{HT}_{2 \mathrm{~A}}$ receptors in frontal cortex in drug-free depressed patients has been observed in a positron emission tomography (PET) study (Biver et al, 1997; Attar-Levy et al, 1999; Yatham et al, 2000). Biegon et al (1990) suggested that $5-\mathrm{HT}_{2 \mathrm{~A}}$ receptor binding on blood platelet is a state-dependent marker in depression. Thus, it is possible that the density of $5-\mathrm{HT}_{2 \mathrm{~A}}$ 
receptors might change in the clinical course of affective disorders. It is reported, as mentioned above, that $\mathrm{Ca}$ response to $5-\mathrm{HT}$ in the platelet could be a trait-dependent rather than a state-dependent value (Kusumi et al, 1994; Tomiyoshi et al, 1999). In the present study, no positive correlation between the density of $5-\mathrm{HT}_{2 \mathrm{~A}}$ receptors and intracellular $\mathrm{Ca}$ response to 5-HT was found in platelets with normal subjects. This result suggests that the number of $5-\mathrm{HT}_{2 \mathrm{~A}}$ receptors may not influence platelet intracellular Ca mobilization after 5-HT stimulation. Therefore, even in the case of the platelets of affective disorders, it is unlikely that increased Ca response to 5-HT may be because of the number of $5-\mathrm{HT}_{2 \mathrm{~A}}$ binding sites. Further studies are required to investigate the correlation between the two measures in the platelet of patients with affective disorders. Ca mobilization elicited by thrombin has been also reported to be enhanced in platelets with bipolar disorder, but not in unipolar depressive disorder (Dubovsky et al, 1991; Kusumi et al, 1992). Thus, there might be some alterations in intracellular signal transduction in platelets with bipolar disorder that are common to both the 5-HT- and thrombininduced Ca mobilizing pathways, which is not influenced by the density of $5-\mathrm{HT}_{2 \mathrm{~A}}$ receptors.

Although we failed to observe the difference in 5-HTinduced platelet intracellular $\mathrm{Ca}$ increase between patients and controls in this study, we showed apparent higher Ca response to 5-HT in bipolar disorder than unipolar depression and normal control in the presence of staurosporine. Two reasons can be considered for the failure in this study to produce the difference in 5-HT-elicited Ca mobilization among three groups in the absence of staurosporine.

First, the sample number examined in this study is relatively small compared with the previous report. The Ca mobilization in bipolar disorder was larger than that in control and unipolar depression, but it was not statistically significant. Enhanced platelet intracellular Ca response to 5HT in untreated affective disorder is a relatively common finding except one report (Bothwell et al, 1994). In our previous report, both unipolar and bipolar disorder patients showed higher Ca response to 5-HT compared with control (Kusumi et al, 1994). However, the Ca mobilization in patients whose diagnoses have changed from unipolar depression to bipolar disorder, during the follow-up for a period of 8-10 years, was significantly higher than in patients whose diagnoses remain unipolar depression (Suzuki et al, 2001).

Second, we intended to choose control subjects in this study who had showed relatively high Ca response to 5-HT in the previous trial, for the purpose of defining the pathophysiology of bipolar disorder. Although the Ca response in the platelet induced by $5-\mathrm{HT}$ is a stable biological index (Kusumi et al, 1991a), there exists some normal subjects whose $\mathrm{Ca}$ response show relatively high value to a degree of bipolar disorder patients. In other words, even if relatively high response to $5-\mathrm{HT}$ is obtained in the platelets from normal control and major depressive disorder, we may be able to clarify whether the diagnosis of the subject is bipolar disorder or not, by means of preincubating platelets with staurosporine.

Staurosporine, a nonspecific protein kinase inhibitor, is often used as a PKC inhibitor because it is reported to inhibit PKC at the nanomolar level (Tamaoki et al, 1986). Half maximal concentration of staurosporine to inhibit purified PKC activity interacting with the ATP-binding site has been reported to be 2-6nM (Tamaoki et al, 1986; Meyer et al, 1989; Asano et al, 1995). Staurosporine at a concentration lower than $100 \mathrm{nM}$ had no remarkable effect on 5-HT-induced platelet intracellular $\mathrm{Ca}$ increase in the present study. Human platelets contain $\alpha$-, $\beta$-, $\delta$-, and $\zeta$-PKC isozymes (Wang et al, 1999). In these isozymes, the activity of purified $\zeta$-PKC is reported to be not sufficiently inhibited by staurosporine at concentrations lower than $100 \mathrm{nM}$ (Geiges et al, 1997). Wang and Friedman (1996, 2001) suggested that membrane-associated $\zeta$-PKC was elevated in bipolar disorder brains. If $\zeta$-PKC are related to the mechanism of agonist-induced Ca mobilization, inhibition of this isozyme may be responsible for reduced Ca mobilization by staurosporine at concentrations higher than $100 \mathrm{nM}$, that is demonstrated in platelets from normal subjects, and increased activity of this isozyme in bipolar disorder patients may prevent this inhibitory effect of $100 \mathrm{nM}$ staurosporine. However, staurosporine at $100 \mathrm{nM}$ can also inhibit cyclic AMP-dependent protein kinase (PKA), phosphorylase kinase, tyrosin kinase, and other kinases (Meyer et al, 1989). And 5-HT has been reported not to translocate $\zeta$-PKC in platelets from cytosol to membrane (Wang et al, 1999). The precise mechanism of inhibitory effect of $100 \mathrm{nM}$ staurosporine on Ca mobilization observed in this study remains to be complicated. Staurosporine at $100 \mathrm{nM}$ seems at least to act on the protein related to the regulation of $\mathrm{Ca}$ release from intracellular $\mathrm{Ca}$ storage site and decrease the Ca mobilization, because with preincubation with $100 \mathrm{nM}$ staurosporine, 5 -HT-induced Ca mobilization also reduced in the absence of external $\mathrm{Ca}$ in healthy subjects (62.8\% of control) (data not shown).

In conclusion, this study suggests that enhanced 5-HTinduced platelet intracellular $\mathrm{Ca}$ mobilization in bipolar disorder may have a relation with increased activity of PKC rather than increased $5-\mathrm{HT}_{2 \mathrm{~A}}$ receptor number. And there is a possibility that measurement of platelet intracellular $\mathrm{Ca}$ response both in the absence and presence of staurosporine could be a specific biological marker for unipolar-bipolar dichotomy.

\section{REFERENCES}

Affolter H, Erne P, Buergisser E, Pletscher A (1984). $\mathrm{Ca}^{2+}$ as messenger of 5HT2-receptor stimulation in human blood platelets. Naunyn-Schmiedeberg's Arch Pharmacol 325: 337-342.

Arora RC, Meltzer HY (1989). Increased serotonin2 (5-HT2) receptor binding as measured by $3 \mathrm{H}$-lysergic acid diethylamide (3H-LSD) in the blood platelets of depressed patients. Life Sci 44: 725-734.

Asano M, Matsunaga K, Miura M, Ito KM, Seto M, Sakurada K et al (1995). Selectivity of action of staurosporine on $\mathrm{Ca}^{2+}$ movements and concentrations in vascular smooth muscles. Eur J Pharmacol 294: 693-701.

Attar-Levy D, Martinet JL, Bin J, Dao-Castellana MH, Crouzel C, Mazoyer B et al (1999). The cortical serotonin2 receptors studied with positron-emission tomography and $[18 \mathrm{~F}]$ setoperone during depressive illness and antidepressant treatment with clomipramine. Biol Psychiatry 15: 180-186. 
Biegon A, Essar N, Israeli M, Elizur A, Bruch S, Bar-Nathan AA (1990). Serotonin 5- $\mathrm{HT}_{2}$ receptor binding on blood platelets as a state dependent marker in major affective disorder. Psychopharmacology 102: 73-75.

Biegon A, Weizman A, Karp L, Ram A, Tiano S, Wolff M (1987). Serotonin 5-HT2 receptor binding on blood platelets: a peripheral marker for depression? Life Sci 41: 2485-2492.

Biver F, Wikler D, Lotstra F, Damhaut P, Goldman S, Mendlewicz J (1997). Serotonin 5- $\mathrm{HT}_{2}$ receptor imaging in major depression: Focal changes in orbitor-insular cortex. Br J Psychiatry 171: 444448.

Bothwell RA, Eccleston D, Marshall E (1994). Platelet intracellular calcium in patients with recurrent affective disorders. Psychopharmacology 114: 375-381.

Cheetham SC, Crompton MR, Katona CLE, Horton RW (1988). Brain 5-HT2 receptor binding sites in depressed suicide victims. Brain Res 443: 272-280.

Cowen PJ, Charig EM, Fraser S, Elliott JM (1987). Platelet 5-HT receptor binding during depressive illness and tricyclic antidepressant treatment. J Affect Disord 13: 45-50.

de Chaffoy de Courcelles D, Leysen JE, De Clerck F, Van Belle H, Janssen PA (1985). Evidence that phospholipid turnover is the signal transducing system coupled to serotonin- $\mathrm{S}_{2}$ receptor sites. J Biol Chem 260: 7603-7608.

Dubovsky SL, Lee C, Christiano J, Murphy J (1991). Elevated platelet intracellular calcium concentration in bipolar depression. Biol Psychiatry 29: 441-450.

Eckert A, Riemann GD, Aldenhoff J, Mueller WE (1993). Elevated intracellular calcium levels after $5-\mathrm{HT}_{2}$ receptor stimulation in platelets of depressed patients. Biol Psychiatry 34: 565-568.

Friedman E, Wang HY, Levinson D, Connel TA, Singh H (1993). Altered platelet protein kinase $\mathrm{C}$ activity in bipolar affective disorder, manic episode. Biol Psychiatry 33: 520-525.

Geiges D, Meyer T, Marte B, Vanek M, Weissgerber G, Stabel S et al (1997). Activation of protein kinase $C$ subtypes $\alpha, \gamma, \delta, \varepsilon, \zeta$, and $\eta$ by tumor-promoting and nontumor-promoting agents. Biochem Pharmacol 53: 865-875.

Grynkiewicz G, Poenie M, Tsien RY (1985). A new generation of $\mathrm{Ca}^{2+}$ indicators with greatly improved fluorescence properties. $J$ Biol Chem 260: 3440-3450.

Hrdina PD, Bakish D, Chudzik J, Ravindran A, Lapierre I (1995). Serotonergic markers in platelets with major depression: upregulation of 5- $\mathrm{HT}_{2}$ receptors. J Psychiatr Neurosci 20: 11-19.

Kagaya A, Mikuni M, Yamamoto H, Takahashi K (1990). Serotonin-induced acute desensitization of serotonin2 receptors in human platelets via a mechanism involving protein kinase C. $J$ Pharmacol Exp Ther 255: 305-311.

Kusumi I, Koyama T, Yamashita I (1991a). Effect of various factors on serotonin-induced $\mathrm{Ca}^{2+}$ response in human platelets. Life Sci 48: $2405-2412$.

Kusumi I, Koyama T, Yamashita I (1991b). Serotonin-stimulated $\mathrm{Ca}$ response is increased in the blood platelets of depressed patients. Biol Psychiatry 30: 310-312.

Kusumi I, Koyama T, Yamashita I (1992). Thrombin-induced platelet calcium mobilization is enhanced in bipolar disorder. Biol Psychiatry 32: 731-734.

Kusumi I, Koyama T, Yamashita I (1994). Serotonin-induced platelet intracellular calcium mobilization in depressed patients. Psychopharmacology 113: 322-327.

Kusumi I, Suzuki K, Sasaki Y, Takahashi Y, Kameda K, Koyama T (2000). Treatment response in depressed patients with enhanced calcium mobilization stimulated by serotonin. Neuropsychopharmacology 23: 690-696.

McBride PA, Brown RP, DeMeo M, Kelip J, Mieczkwoski T, Mann JJ (1994). The relationship of platelet 5- $\mathrm{HT}_{2}$-receptor indices to major depression disorder, personality traits and suicidal behavior. Biol Psychiatry 35: 295-308.
McBride PA, Mann JJ, McEwen B, Biegon A (1983). Characterization of serotonin binding sites on human platelets. Life Sci 33: 2033-2041.

McKeith IG, Marshall EF, Ferrie IN, Armstrong MM, Kennedy WN, Perry RH et al (1987). 5-HT receptor binding in post-mortem brain from patients with affective disorder. J Affect Disord 13: 67-74.

Meyer T, Regenass U, Fabbro D, Alteri E, Rosel J, Muller M et al (1989). A derivative of staurosporine (CGP 41 251) shows selectivity for protein kinase $\mathrm{C}$ inhibition and in vitro antiproliferative as well as in vivo anti-tumor activity. Int J Cancer 43: 851-856.

Mikuni M, Kagaya A, Takahashi K, Meltzer HY (1992). Serotonin but not norepinephrine-induced calcium mobilization of platelets is enhanced in affective disorders. Psychopharmacology 106: 311-314.

Neuger J, El Khoury A, Kjellman BF, Wahlund B, Aberg-Wistedt A, Stain-Malmgren R (1999). Platelet serotonin functions in untreated major depression. Psychiatry Res 85: 189-198.

Okamoto Y, Kagaya A, Shinno H, Motohashi N, Yamawaki S (1994). Serotonin-induced platelet calcium mobilization is enhanced in mania. Life Sci 56: 327-332.

Pandey GN, Dwivedi Y, Kumari R, Janicak PG (1998). Protein kinase $\mathrm{C}$ in platelets of depressed patients. Biol Psychiatry 44: 909-911.

Pandey GN, Pandey SC, Janicak PG, Marks RC, Davis JM (1990). Platelet serotonin-2 receptor binding sites in depression and suicide. Biol Psychiatry 28: 215-222.

Rittenhouse-Simmons S (1979). Production of diglyceride from phosphatidylinositol in activated human platelets. J Clin Invest 63: 580-587.

Sheline YI, Bardgett ME, Jackson JL, Newcomer JW, Csernansky JG (1995). Platelet serotonin markers and depressive symptomatology. Biol Psychiatry 37: 442-447.

Suzuki K, Kusumi I, Sasaki Y, Koyama T (2001). Serotonininduced platelet intracellular calcium mobilization in various psychiatric disorders: is it specific to bipolar disorder? J Affect Disord 64: 291-296.

Tamaoki T, Nomoto H, Takahashi I, Kato Y, Morimoto M, Tomita F (1986). Staurosporine, a potent inhibitor of phospholipid/Ca ${ }^{2+}$ dependent protein kinase. Biochem Biophys Res Commun 135 397-402.

Tomiyoshi R, Kamei K, Muraoka S, Muneoka K, Takigawa M (1999). Serotonin-induced intracellular $\mathrm{Ca}^{2+}$ responses in untreated depressed patients and imipramine responders in remission. Biol Psychiatry 45: 1042-1048.

Velayudhan A, Sunitha TA, Balachander S, Reddy JYC, Khanna S (1999). A study of platelet serotonin receptor in mania. Biol Psychiatry 45: 1059-1062.

Wang H-Y, Friedman E (1996). Enhanced protein kinase C activity and translocation in bipolar affective disorder brains. Biol Psychiatry 40: 568-575.

Wang H-Y, Friedman E (2001). Increased association of brain protein kinase $\mathrm{C}$ with the receptor for activated $\mathrm{C}$ kinase-1 (RACK1) in bipolar affective disorder. Biol Psychiatry 50: 364370.

Wang H-Y, Markowitz P, Levinson D, Undie AS, Friedman E (1999). Increased membrane-associated protein kinase C activity and translocation in blood platelets from bipolar affective disorder patients. J Psychiatr Res 33: 171-179.

Yates M, Leake A, Candy JM, Fairbrairn AF, McKieth IG, Ferrier IN (1990). 5- $\mathrm{HT}_{2}$ receptor changes in major depression. Biol Psychiatry 27: 489-496.

Yatham LN, Liddle PF, Shiah I, Scarrow G, Lam RW, Adam MJ et al (2000). Brain serotonin2 receptors in major depression: a positron emission tomography study. Arch Gen Psychiatry 57: $850-858$. 